\title{
Chemopreventive Target for Prostate Cancer: Prostatic Intraepithelial Neoplasia
}

\author{
J. Arunakaran ${ }^{1}$, S. Banudevi ${ }^{1}$ and A. Arunkumar ${ }^{2}$ \\ ${ }^{1}$ Department of Endocrinology, Dr. ALM Post Graduate Institute of Basic Medical \\ Sciences, University of Madras, Sekkizhar Campus, Taramani, Chennai Tamilnadu, \\ ${ }^{2}$ Center of Excellence in Cancer Research, Department of Biomedical Sciences, \\ Texas Tech University Health Sciences Center, Texas \\ India \\ ${ }^{2}$ USA
}

\section{Introduction}

Prostate cancer is one of the most frequently diagnosed malignancies among the male population and the second common cancer-related death worldwide after lung cancer (Jemal et al., 2010). It is estimated that 30\% of male older than 50 years are harboring microscopic transformation of adenocarcinoma within the prostate gland. Because of the dramatic rise in the incidence of prostate cancer with the rate increasing approximately $6 \%$ per year worldwide (Eschenbach, 1996), the study of precursor lesions of prostate cancer is emerging concept in the field of prostate cancer prevention.

\section{Prostatic intraepithelial neoplasia}

John McNeal introduced the term intraductal dysplasia of the prostate in the early 1960s, postulating that carcinoma of the prostate arose from active ductal/acinar epithelium and not from atrophic acini (McNeal, 1965, 1988; Amin et al., 1993). Later various terms have been rasied such as large acinar atypical hyperplasia with malignant change (Allam et al., 1996) and ductacinar dysplasia (McNeal, 1988). None of these have gained popularity. The term Prostatic intraepithelial neoplasia (PIN) was first proposed by Bostwick and Brawer in 1987, and this term was accepted at the 1989 Workshop on Prostatic Dysplasia (Bethesda, Md; March 1989) as the preferred nomenclature for this preneoplastic change (Bethesda, Md; March 1989; Drago et al., 1989). PIN refers to the putative precancerous end of the continuum of cellular proliferations within the lining of prostatic ducts, ductules and acini (Bostwick and Amin, 1996; Bostwick and Qian, 2004).

PIN is the most likely precursor of prostate cancer and has been described as a premalignant or pre-invasive form of prostate cancer (Sakr et al., 1993; Bostwick, 1996). Although two histopathologic lesions in the prostate were proposed as being premalignant (PIN and atypical adenomatous hyperplasia, AAH), there is less evidence of a premalignant role for AAH than there is for PIN (De La Torre et al., 1993; Jones and Young, 1994; Epstein, 1994; Bostwick, 1996). Within these lesions, studies have identified impaired and abnormal 
differentiation, increased proliferation, and abnormal DNA content and elevated ras protooncogene mRNA expression (Jones and Young, 1994). There are two grades of PIN (low-grade and high-grade), although the term PIN is usually used to indicate high-grade PIN (HGPIN). The high level of interobserver variability with low-grade PIN (LGPIN) limits its clinical utility, and many pathologists do not report this finding except in research studies. Low grade PIN (LGPIN) is only a very early precursor, and might even not be considered as a precancerous lesion. Moreover, the distinction between LGPIN and normal epithelium might be observer related (Lipski et al., 1996; Zlotta and Schulman, 1999; Vis and Van der Kwast, 2001).

PIN lesions can only be diagnosed by histopathological examination of prostatic tissue. It is impossible to detect PIN clinically by digital rectal examination (DRE), prostate specific antigen (PSA) or ultrasound. Cytologically, LGPIN and HGPIN have clear and reproducible features (Table 1). Histologically, however, different architectural variations exist for HGPIN (Fig. 1). At least four distinct patterns can be distinguished: flat, tufting, micropapillary and cribriform (Bostwick, 1989). Less frequent are signet cell pattern, small cell neuroendocrine pattern, mucinous pattern and microvacuolar pattern. In the big majority of PIN-lesions, a tufting pattern can be found. Frequently, multiple patterns can be found at the same time.

\begin{tabular}{lll}
\hline $\begin{array}{l}\text { Structural } \\
\text { pattern }\end{array}$ & Low grade PIN (LGPIN) & High grade PIN (HGPIN) \\
\hline Architecture & $\begin{array}{l}\text { Crowding, stratification, } \\
\text { irregular spacing }\end{array}$ & $\begin{array}{l}\text { More changes, 4 patterns (T, MP, } \\
\text { cribriform, flat)* }\end{array}$ \\
$\begin{array}{l}\text { Nuclei } \\
\text { Chromatin }\end{array}$ & $\begin{array}{l}\text { Slight enlargement, size } \\
\text { variation } \\
\text { Normal } \\
\text { Rarely prominent }\end{array}$ & $\begin{array}{l}\text { Definite enlargement, less size } \\
\text { variation } \\
\text { Increased density and clumping } \\
\text { Frequently prominent }\end{array}$ \\
Basal cell layer & Intact & $\begin{array}{l}\text { May show some disruption } \\
\text { Basement }\end{array}$ \\
membrane & Intact & Intact \\
\hline
\end{tabular}

* T indicates tufting; MP- micropapillary.

Table 1. Prostatic intraepithelial neoplasia (PIN): diagnostic criteria modified from Bostwick and Brawer (1987)

HGPIN is the most significant risk factor for prostate cancer in needle biopsy specimens. Its role as the preinvasive stage of cancer was recently confirmed conclusively in two separate mouse models (Kasper et al., 1998; Garabedian et al., 1998). PIN coexists with cancer in more than $85 \%$ of cases (McNeal and Bostwick, 1986; Qian et al., 1997) but retains an intact or fragmented basal cell layer, unlike cancer, which lacks a basal cell layer (Bostwick and Brawer, 1987). PIN is strongly predictive of adenocarcinoma, and its identification in biopsy 
specimens of the prostate warrants further search for concurrent cancer. PIN alone has no apparent influence on serum PSA concentration, and it is not apparently visible by current imaging techniques.

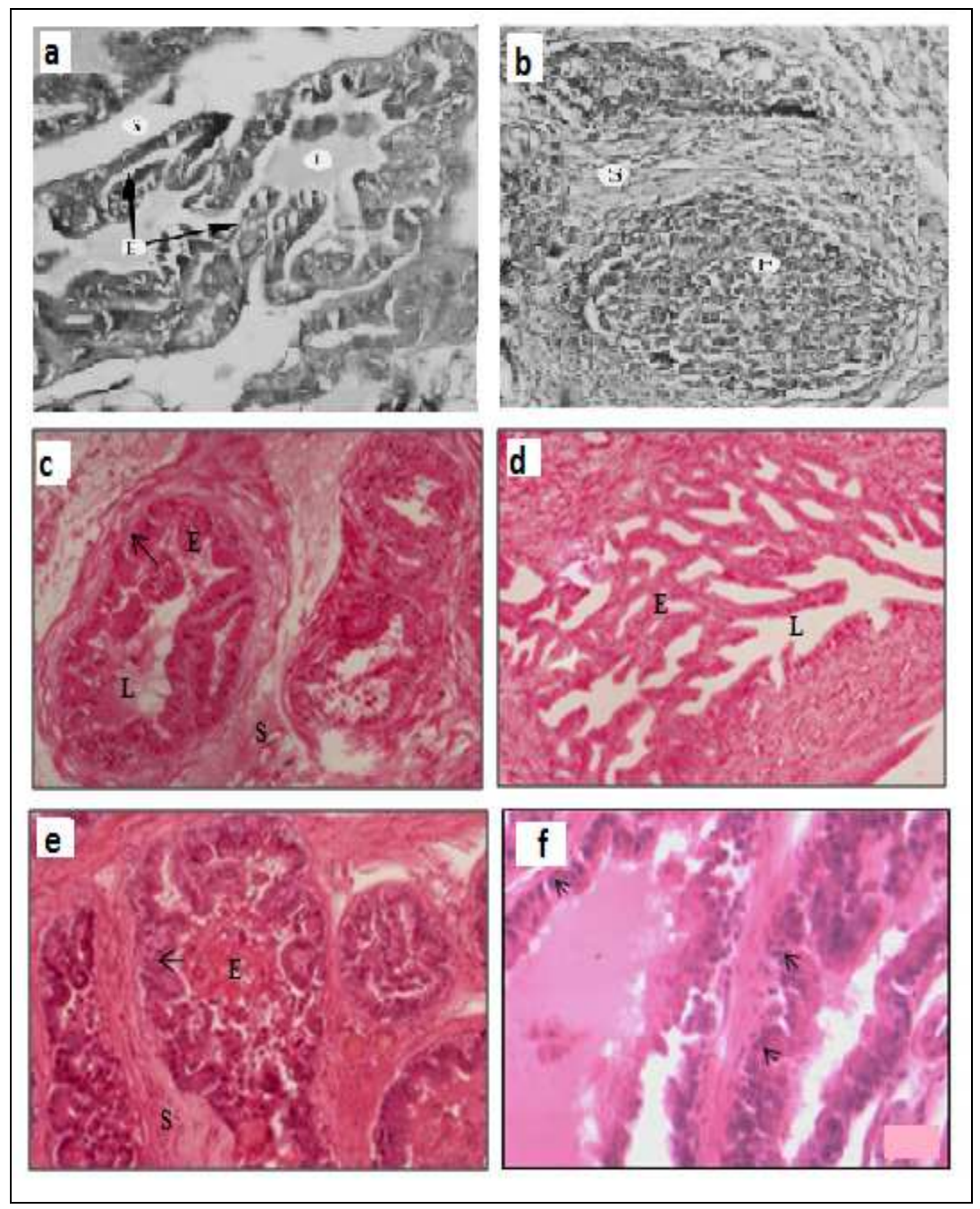

Fig. 1. Prostatic intraepithelial neoplasia Histology. (a). Multiple dysplastic and hyperplastic sites were seen within the same glandular epithelium $(\times 200$ magnifications; H\&E) (b). Fully developed PIN with loss of basal epithelial cells ( $\times 200$ magnifications; H\&E) (Arunkumar et al., 2006). Architectural pattern of high grade prostatic intraepithelial neoplasia (PIN) such as tufting (c), cribriform (d), and micropapillary (e) structures were observed ( $\times 200$ magnifications; H\&E) (f). The cell number in PIN was markedly increased, and cell density with sparse cytoplasm (arrow headed) ( $\times 400$ magnifications; H\&E) (Banudevi et al., 2011a \& b). E- Epithelium; L- Lumen; S-Stroma 


\section{Identification of PIN: Histological criteria}

The classification of PIN into low grade and high grade is based mainly on the cytological characteristics of the cells. The nuclei of cells composing LGPIN are enlarged, vary in size, have normal or slightly increased chromatin content, and possess small or inconspicuous nucleoli (Figs. 2 and 3). HGPIN is characterised by cells with large nuclei of relatively uniform size, an increased chromatin content, which might be irregularly distributed, and prominent nucleoli that are similar to those of carcinoma cells (Fig. 4). The basal cell layer is intact or rarely interrupted in LGPIN, but may have frequent disruptions in high grade lesions. Although the cytological features of LGPIN and HGPIN are fairly constant, the architecture shows a spectrum, varying from a flattened epithelium to a florid cribriform proliferation. Four basic patterns that often coexist have been described by Bostwick and colleagues (Bostwick et al., 1993): flat, tufting, micropapillary, and cribriform. Familiarity with this diverse architectural spectrum may facilitate the histological recognition of PIN, even though these various architectural patterns have no apparent clinicopathological relevance (Bostwic et al., 1993).

Neuroendocrine differentiation occurs in PIN, where it is intermediate in degree between normal prostate (which has the most cells with neuroendocrine differentiation) and carcinoma (Bostwick et al., 1994a; Di Sante Agnese, 1996). Paneth cell like change of the prostatic epithelium (neuroendocrine cells with large eosinophilic granules) is considered to be a distinct form of neuroendocrine differentiation characterised by isolated cells or small groups of cells with prominent eosinophilic cytoplasmic granules.

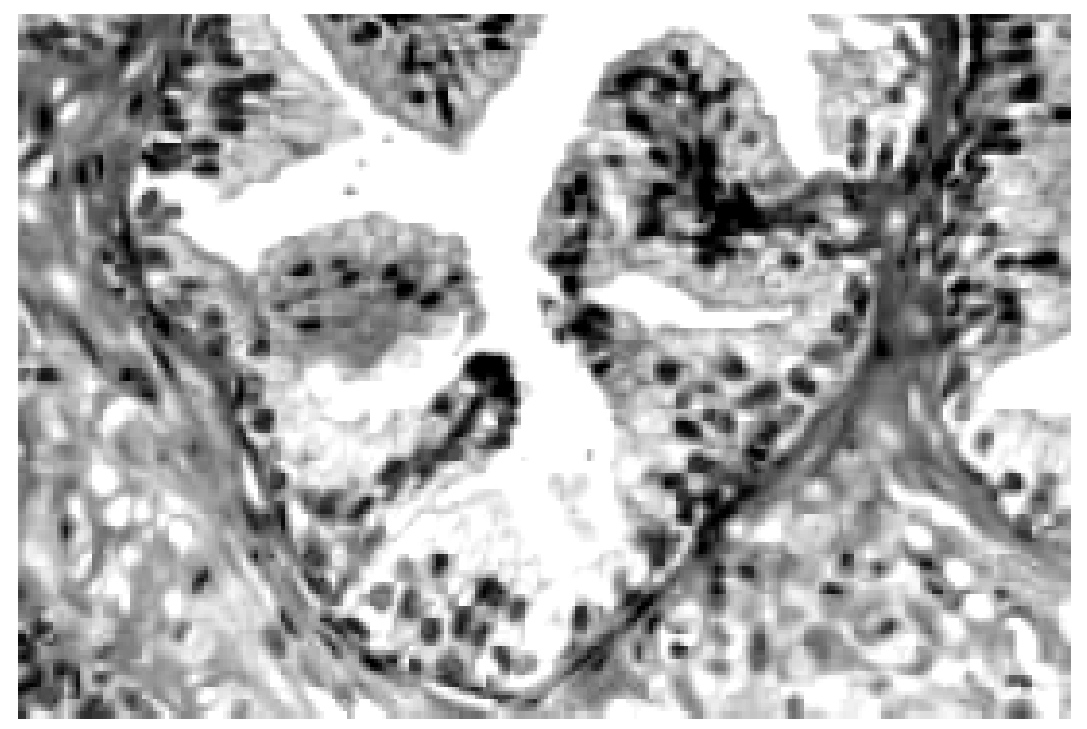

Fig. 2. Normal prostate. The duct is lined by a two cell layer- for example, the basal cell and the secretory or luminal cell layers. 


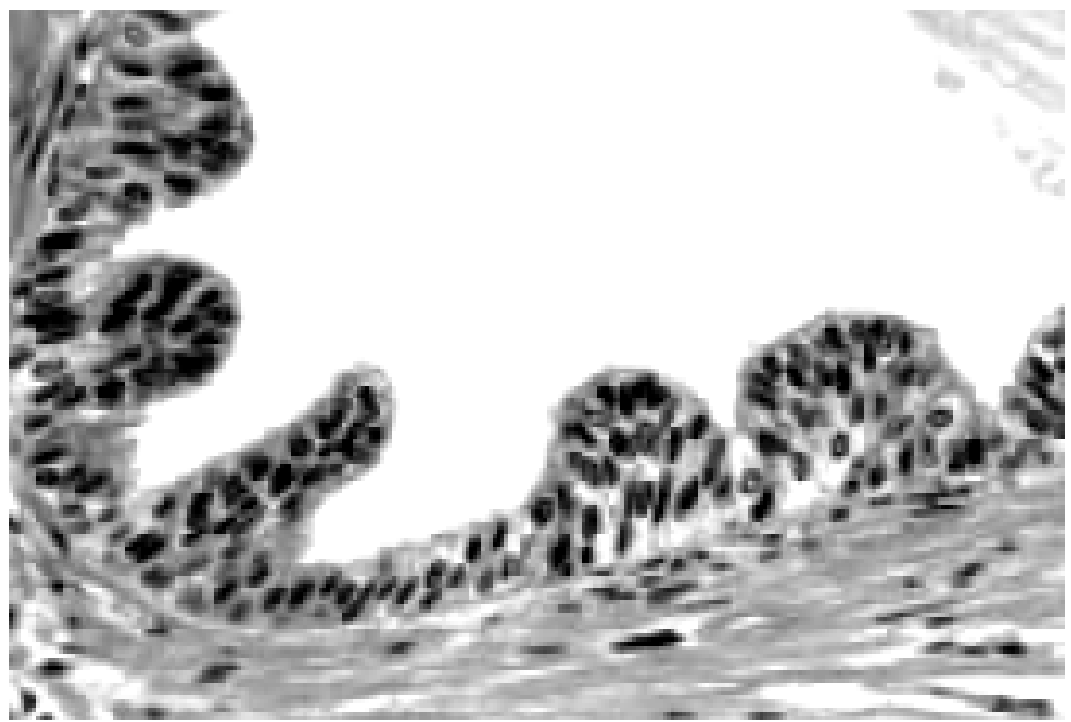

Fig. 3. Low grade prostatic intraepithelial neoplasia. The nuclei of the secretory cells are enlarged, vary in size, have normal or slightly increased chromatin content, and possess small or inconspicuous nucleoli. The basal cell layer is almost intact.

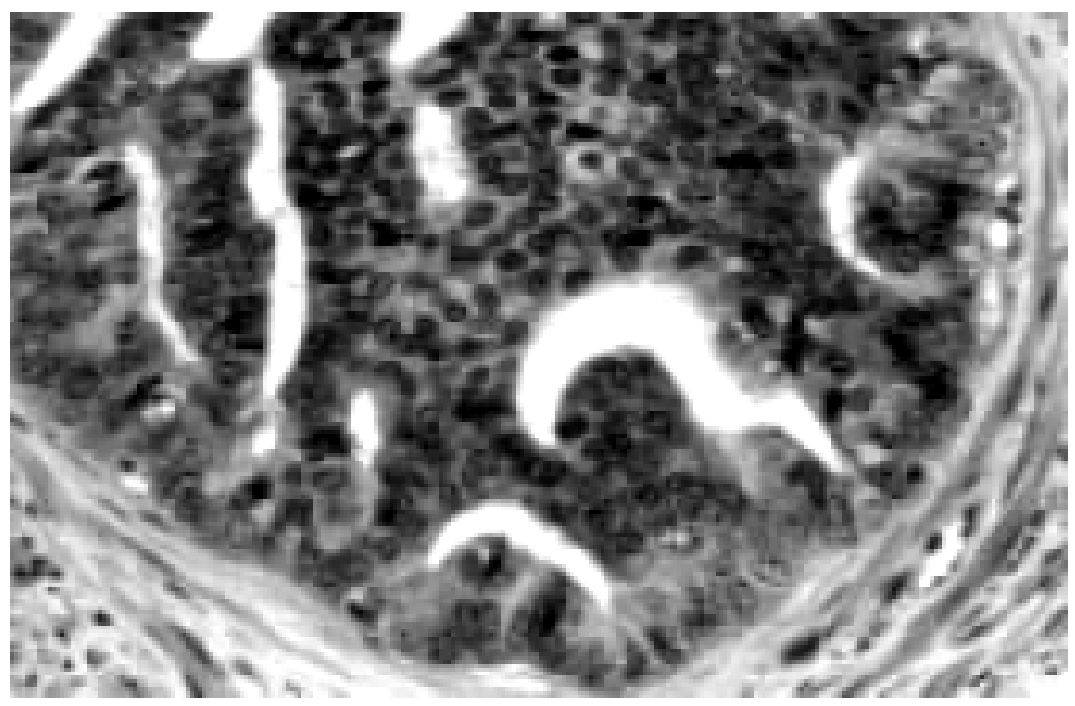

Fig. 4. High grade prostatic intraepithelial neoplasia with cribriform patterns. The perimeter cells show features of clearly dysplastic cells, whereas, going from the periphery towards the centre, the nuclei become smaller and the nucleoi become less apparent ("maturation phenomenon"). The basal cell layer is disrupted. 


\section{PIN incidence}

The incidence of PIN varies according to the male population. The lowest likelihood is in men participating in PSA screening and early detection studies, with an incidence of PIN in biopsies ranging from 0.7\% to 20\% (Bostwick et al., 1996; Langer et al., 1996; Wills et al., 1997; Skjorten et al., 1997). Men seen by urologists in practice have PIN in $4.4 \%$ to $25 \%$ of contemporary 18-gauge needle biopsies obtained by urologists. Those undergoing transurethral resections have the highest likelihood of PIN, varying from $2.8 \%$ to $33 \%$ (Pacelli et al., 1997). In such cases, all tissues should be examined, but serial sections of suspicious foci are probably not usually necessary. Select anti-keratin antibodies such as $34 \beta$-E12 (high molecular weight keratin) may be used to stain tissue sections for the presence of basal cells, recognizing that PIN retains intact or fragmented basal cell layer, whereas cancer does not (Bostwick and Brawer, 1987). By immunohistochemical analysis, Prostate tumor overexpressed-1 (PTOV1) was considered as good marker for PIN which shows strong immunoreactivity in areas of carcinoma and HGPIN (Morote et al., 2008)

\section{PIN distribution}

Prostatic intraepithelial neoplasia is found predominantly in the peripheral zone of the prostate $(75 \%-80 \%)$, rarely in the transition zone $(10 \%-15 \%)$, and extremely rarely in the central zone $(<5 \%)$. This distribution parallels the frequency of the zonal predilection for prostatic carcinoma (Bostwick et al., 1995; Gaudin et al., 1997,; Pacelli et al., 1997). The frequency of HGPIN in needle biopsy series ranges from $5 \%$ to $16 \%$ and in transurethral resection of the prostate specimens between 2.3\% and 4.2\% (Bostwick et al., 1995; Gaudin et al., 1997; Melissari et al., 2006) McNeal in 1969 mentioned the multifocality of this process (McNeal, 1969; 1988); this observation has since been corroborated by others.

\section{Immunohistochemistry in PIN}

Numerous studies to highlight the basal cells and the secretory cells have been done (Brawer et al., 1985; McNeal et al., 1988a, 1988b; Perlman and Epstein, 1990; Abhrams et al., 2002; Zhou et al., 2003; Wu et al., 2004). The basal cells and luminal cells of the prostatic glands display different keratin immunoreactivity. The high-molecular-weight cytokeratin monoclonal antibody (clone 34ßE12, also referred to as CK903) recognizes keratin proteins of 49,51,57, and $66 \mathrm{kD}$ and labels the basal cells but not the luminal/secretory cells of the prostatic glands that stain with prostate-specific antigen and prostatic acid phosphatase. a-Methylacyl CoA-racemase (AMACR) stains the cells of adenocarcinoma but usually does not stain benign prostate glands (Brawer et al., 1985; McNeal et al., 1988a, 1988b; Perlman and Epstein, 1990; Abhrams et al., 2002; Zhou et al., 2003; Wu et al., 2004).

Other antibodies that also mark basal cells include p63 (McNeal, 1969) and CK5/6 (Abhrams et al., 2002). p63 is a nuclear stain, whereas CK5/6 stains the cytoplasm (Abhrams et al., 2002; Zhou et al., 2003). The basal cell layer is present in benign epithelial proliferations, may be disrupted in HGPIN, and is absent in invasive carcinoma (Bostwick and Brawer , 1987). Bostwick and Brawer in 1987 have shown that the frequency and extent of basal cell disruption in PIN is related to the PIN grade and is greatest in HGPIN. 
A numerous of Immuno histochemical studies (McNeal et al., 1988a; Perlman and Epstein, 1990; Deschenes and Weidner, 1990; Nagle et al., 1991; Sesterhenn et al., 1991) have been done to correlate the relationship between HGPIN and invasive carcinoma, Including evaluation of monoclonal antikeratin antibody, KA4, Ulex europaeus lectin (UEA-1), lectin binding pattern, and vimentin. Wu et al. demonstrated that a significantly higher P504S (AMACR) positive rate $(56.0 \%)$ was found in isolated HGPIN glands adjacent to cancer (distance less than $5 \mathrm{~mm}$ ) compared with those away from cancer (distance more than 5 $\mathrm{mm} ; 14 \%, P<0.001$ ) (Wu et al., 2004). High-grade PIN glands adjacent to cancer also showed a higher $(P<0$.001) P504S intensity than did those away from cancer.

Other studies including argyrophilic nucleolar organizer regions and static DNA flow cytometry suggest that HGPIN and carcinoma have similar proliferative activity and DNA content, and hence HGPIN is the most likely precursor of cancer (Sesterhenn et al., 1991; Weinberg and Weidner, 1993; Amin et al., 1994). Cytogenetic abnormalities (involving 7q, $8 \mathrm{q}, 10 \mathrm{q}, 16 \mathrm{q})$ and numerical chromosomal changes are noted in HGPIN and carcinoma (Emmert-Buck et al., 1995; Macoska et al., 1995; Qian et al., 1999; Al-Maghrabi et al., 2002). High-grade PIN and prostate cancer share genetic and molecular markers as well, with PIN representing an intermediate stage between benign epithelium and invasive carcinoma (Brawer, 2005).

PIN offers promise as an intermediate endpoint in studies of chemoprevention of prostatic carcinoma (Bostwick et al., 1994b; Aquilina et al., 1997). Recognizing the slow growth rate of prostate cancer and the considerable amount of time needed in animal and human studies for adequate follow-up, the non-invasive precursor lesion PIN is a suitable intermediate histologic marker to indicate subsequent likelihood of cancer (Aquilina et al., 1997).

\section{Chemoprevention strategies}

Chemoprevention is the administration of agents to prevent induction of cancer, or to inhibit or delay its progression. In prostatic neoplasia, the time from tumour initiation and progression to invasive carcinoma often begins in men in the fourth and fifth decades of life and extends across decades. This phenomenon represents a unique opportunity to arrest or reverse the process of carcinogenesis with the use of chemopreventive agents. Animal models in defining efficacy of chemoprevention agents against prostate cancer. Detection of inhibitory effects on de novo prostate cancer development requires a high cancer incidence and similarity of induced tumors to human prostate carcinomas. The following animal models have produced high incidences of multifocal prostate adenocarcinoma: transgenic mice with oncogenes expressed in a prostate specific fashion; Noble rats that have been treated chronically with combination of $17 \beta$-estradiol and testosterone; and Wistar or F344 rats treated sequentially with a single injection of $N$-methyl- $N$-nitrosourea (MNU) and chronic administration of testosterone.

PIN most often occurs in the first two models, and metastases are frequent in some transgenic models and the MNU-testosterone model (Shirai et al., 1991; Pollard et al., 1992; Kadomatsu et al., 1993; Slayter et al., 1994; Ingles et al., 1997). The chemopreventive efficacy of a series of agents using a model in which hormone dependent prostate cancer is induced in the Wistar-Unilever rat (McCormick, 1998). This is achieved by sequential treatment with 
an antiandrogen (cyproterone acetate), and androgen (testosterone propionate) and a direct acting chemical carcinogen (N-methyl-N-nitrosourea), followed by chronic androgen stimulation (testosterone). This regimen reproducibly induces a high incidence $(<75 \%)$ of prostate cancer, with no gross toxicity and a low incidence of neoplasia in the seminal vesicles and other non-target tissue.

Dehydroepiandrosterone (DHEA) and 9-cis-retinoic acid (9-cis-RA) are the most active chemopreventive agents identified to date. DHEA inhibits the induction of prostate cancer when administration is started before carcinogen exposure, and when it is delayed until incipient neoplastic lesions are present. Chronic administration of 9-cis-RA starting before carcinogen exposure is highly effective in the chemoprevention of prostate cancer. Liarozole fumarate confers modest protection against induction of prostate cancer, whereas $\mathrm{N}-(4-$ hydroxyphenyl) retinamide (4-HPR), a-difluoromethylornithine, DL-a-tocopherol acetate (vitamin E), oltipraz, and L-selenomethionine are inactive. The differential activity of 9-cis-RA and 4-HPR suggests the ligand specificity may be a determinant of retinoid action in prostate cancer chemoprevention. Chemoprevention of $\mathrm{MNU}+\mathrm{T}$ induced prostate carcinogenesis at low dose level $(0.5 \mu \mathrm{g} / \mathrm{kg}$ body weight $)$ of calcitriol has significant potency to inhibit prostatic hyperplasia, dysplasia and PIN, and also decreased serum PAcP activity. Calcitriol may be an effective therapy for the treatment of early prostate cancer (Senthil kumar et al., 2006).

Christov et al. (2002) studied that PIN can be used for assessing the efficacy of chemopreventive agents on prostate carcinogenesis. Dially disulfide, an organosulfur compound of garlic, has significant potency as an inhibitor of cancer induction in Sprague Dawley rat prostate by inhibiting PIN, hyperplastic and dysplastic foci (Arunkumar et al., 2006). Zinc also acts as a chemopreventive agent against prostate cancer by inducing regression in PIN (Banudevi et al., 2011a). Zinc inhibits PIN an early stage of prostate cancer. This study proves the ability of zinc to restore the PIN changes particularly in the rat ventral prostate induced by carcinogen and testosterone thereby indicating its anticarcinogenic potential (Banudevi et al., 2011a). As the dorsolateral prostate is most likely homologue to the human prostate (Bosland et al., 1990), in our recent study we proved that zinc was found to inhibit the growth and decrease dorsolateral prostatic acid phosphatase, zinc, citrate levels, phase I drug metabolizing enzyme activities, lipid peroxide, $\mathrm{H}_{2} \mathrm{O}$ levels, proliferating cell nuclear antigen (PCNA), Bcl2, Bcl- $\mathrm{X}_{\mathrm{L}}$ expressions with concomitant increase in phase II enzyme activities, GSH levels, p53, Bax, caspase-3 expressions in MNU testosterone induced model of prostate carcinogenesis (Banudevi et al., 2011b). Signs of dysplasia, a characteristic of prostatic intraepithelial neoplasia, were evident in the dorsolateral prostatic histoarchitecture. Thus, zinc may act as an essential trace element against MNU and testosterone induced prostatic preneoplastic progression in Sprague Dawley rats.

The most efficient strategy for developing a chemoprevention programme is to perform two clinical trials concurrently, each based on the modulation of high grade PIN but in different target populations (Nelson et al., 1996; Bostwick, 1997). In patients with high grade PIN associated with prostate cancer, a prospective, double blind, placebo controlled chemoactive pilot study designed to measure the response of a potential chemopreventive agent in the period (three to six weeks) before radical prostatectomy could easily be performed.

Androgen deprivation treatment is commonly used in this population to downsize the prostate before radical prostatectomy. This study may provide information regarding the 
effectiveness of proposed agents on surrogate endpoint biomarkers, premalignant lesions, and cancer. In particular, such an investigation would determine the response of PIN to the agent in whole mounted radical prostatectomy specimens. In some preliminary investigations it has been shown that there is a marked decrease in the prevalence and extent of PIN in prostates after androgen deprivation treatment, as compared with untreated prostates (Ferguson et al., 1994). This is accompanied by regressive changes in the secretory epithelium. Apoptotic bodies are more often seen in the treated normal prostate, PIN, and prostate cancer than in untreated cases. This suggests that androgen ablation induces epithelial regression by enhancing apoptosis. The low proliferating cell nuclear antigen (PCNA) and Ki67 related values and the absence of mitoses in PIN as well as in normal prostate and prostate cancer in the treated cases indicates suppressed proliferation activity as a consequence of androgen deprivation treatment (Armas et al., 1993; Montironi et al., 1994). It has been reported that angiogenesis is inhibited in prostate lesions when total androgen ablation induces cell regression and activation of the apoptosis (Montironi et al., 1996). Consequently, the epithelial cells are blocked from expressing, producing, or exporting angiogenic molecules. All these findings indicate that the dysplastic prostatic epithelium is hormone dependent.

A short term prospective, double blind, placed controlled phase II chemopreventive trial with cancer as an endpoint could be done in patients with high grade PIN without cancer. Chemoprevention trials designed to reverse high grade PIN may be confounded by the presence of underlying but undetected addressed by requiring a second biopsy with negative findings for cancer before entry into the study (preferably sextant biopsies with special attention to areas of abnormality on ultrasonogram or digital rectal examination), and by including enough subjects in the study and control groups to equalise the risk of coexistent cancer between the two groups.

PIN is routinely monitored by repeat biopsy in contemporary urological practice. Periodic re-evaluation would be necessary, including physical examination, rebiopsy, and evaluation of surrogate intermediate endpoint biomarkers. If subsequent biopsy reveals prostate cancer, these patients need definitive treatment. Those with PIN or no malignancy need continued observation (Bostwick, 1997).

\section{Clinical chemoprevention studies}

Table 2 reports agents, the treatment periods, and the primary endpoints used in clinical chemoprevention studies sponsored or funded by the National Cancer Institute (Kellof, 1997).

\section{Green tea catechins}

Epidemiological and case-control studies have garnered support for the chemopreventive properties of green tea (Jian et al., 2004). A recent study was conducted on 60 volunteers with high-grade prostate intraepithelial neoplasia, a putative precursor of prostate adenocarcinoma (Bettuzzi et al., 2006). Patients received green tea compounds in capsule form $200 \mathrm{mg}$ three times per day. Following 1 year of treatment, only $3 \%$ of patients that received the green tea polyphenols were diagnosed with cancer compared with $30 \%$ in the placebo group. Furthermore, patients that received the green tea capsules exhibited a longer 
latency to tumor detection and exhibited an improved quality of life. Another phase II study, in which $6 \mathrm{~g}$ /day of tea was administered to 42 patients with asymptomatic, androgen- independent prostate cancer, has demonstrated that a single patient achieved a PSA response of $>50 \%$ that lasted for approximately 1 month. These patients suffered with side effects that include diarrhea, nausea and fatigue (Jatoi et al., 2003). Another clinical study used $250 \mathrm{mg}$ dose of green tea polyphenols twice daily. In this study, 6 out of 19 patients had disease control for 3 to 5 months and there was only 1 patient whose PSA rise was affected by green tea supplementation. The dose used in this study did not discernibly alter the course of hormone-refractory prostate cancer (Choan et al., 2005). These results suggest that green tea possesses cancer chemopreventive properties and minimal antineoplastic activity against advance stage prostate cancer.

\begin{tabular}{|c|c|c|}
\hline Agent & Cohort (treatment period) & Primary endpoints \\
\hline \multicolumn{3}{|r|}{ 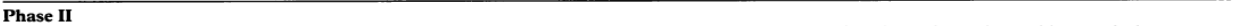 } \\
\hline \multirow[t]{3}{*}{ DFMO } & Scheduled for prostate cancer surgery ( $4-8$ weeks) & $\begin{array}{l}\text { Histopathology (PIN grade, nuclear polymorphism, nucleolar } \\
\text { polymorphism, ploidy), proliferation biomarkers (PCNA, Ki-67) }\end{array}$ \\
\hline & $\begin{array}{l}\text { Scheduled for prostatectomy (stage A or B prostatic carcinoma } \\
\text { or bladder cancer without prostatic carcinoma and scheduled } \\
\text { for cystoprostatectomy) (14 days) }\end{array}$ & $\begin{array}{l}\text { Drug effect measurements: ODC activity (skin and prostate), polyamine } \\
\text { levels (prostate). Histopathology (TRUS guided biopsies). } \\
\text { Biochemical biomarkers: PSA, PAP, testosterone }\end{array}$ \\
\hline & $\begin{array}{l}\text { Serum PSA 3-10 ng/ml (includes patients with prostatic } \\
\text { carcinoma and PIN) (14 days-1 year) }\end{array}$ & $\begin{array}{l}\text { Drug effect measurements: ODC activity (skin and prostate) Polyamine } \\
\text { levels (prostate). Histopathology (TRUS-guided biopsies) Biochemical } \\
\text { biomarkers: PSA, PAP, testosterone }\end{array}$ \\
\hline DHEA & Scheduled for prostate cancer surgery ( 28 days) & $\begin{array}{l}\text { Histopathology (PIN grade, nuclear polymorphism, nucleolar } \\
\text { polymorphism, ploidy). Proliferation biomarkers (PCNA, Ki- } 67 \text { ). } \\
\text { Genetic/regulatory biomarkers (p53,bc1-2, pc-1, chromosome } 8 \mathrm{p} \text { loss) }\end{array}$ \\
\hline Flutamide & Patients with high grade PIN (12 months) & $\begin{array}{l}\text { PIN grade and incidence, cancer incidence, nuclear polymorphism, } \\
\text { nucleolar size, ploidy. Other endpoints: PCNA, angiogenesis, } \\
\text { apoptosis, LOH chromosome 8; growth factors, PSA }\end{array}$ \\
\hline \multirow[t]{3}{*}{ 4-HPR } & $\begin{array}{l}\text { Biopsy proven non-metastatic prostate adenocarcinoma, } \\
\text { scheduled for radical prostatectomy ( } 4 \text { weeks) }\end{array}$ & $\begin{array}{l}\text { Genetic/regulatory biomarkers: TGF } \beta, c-m y c, p 53 \text {, plasminogen } \\
\text { activators (tPA, uPA), apoptosis }\end{array}$ \\
\hline & Scheduled for prostate cancer surgery ( $4-8$ weeks) & $\begin{array}{l}\text { Histopathology: PIN grade, nuclear polymorphism, nucleolar } \\
\text { polymorphism, ploidy. Proliferation biomarkers: PCNA, Ki-67. }\end{array}$ \\
\hline & & $\begin{array}{l}\text { Differentiation biomarkers: Lewis }{ }^{Y} \text { antigen. Genetic/regulatory } \\
\text { biomarkers: p53,EGFR, TGF } \alpha\end{array}$ \\
\hline \multicolumn{3}{|r|}{ Dr } \\
\hline Finasteride & $\begin{array}{l}\text { Men } \geqslant 55 \text { years of age with normal DRE and PSA }<3.0 \mathrm{ng} / \mathrm{ml} \\
(7 \text { years })\end{array}$ & $\begin{array}{l}\text { Prostate cancer incidence (grade and stage), BPH incidence and severity, } \\
\text { overall and prostate-specific mortality, TURP, PSA levels }\end{array}$ \\
\hline Selenised yeast & $\begin{array}{l}\text { Skin cancer (melanoma, non-melanoma) patients, low Se areas in } \\
\text { USA }(\sim 1 \text { year) }\end{array}$ & PSA levels \\
\hline
\end{tabular}

Table 2. National Cancer Institute Chemoprevention Branch: sponsored od funded phase II/III clinical chemoprevention trials: prostate cancer

\section{Selective estrogen receptor modulators (SERMs)}

Interest in SERMs as preventive agents has been stimulated by an apparent role of estrogens in the pathogenesis of prostate cancer, through promotion of cell growth. SERMs are generally considered to be 'weak estrogens' because they possess both agonist and antagonist activities depending on the specific tissue type and on the relative ER subtype interactions. Consequently this class of agents has been called selective estrogen receptor modulators or SERMs. As with phytoestrogens, SERMs appear to possess the ability to suppress prostate carcinogenesis. Toremifene has been evaluated in a phase IIa exploratory trial in men with high-grade PIN (Steiner and Pound, 2003). After 4 months of treatment with a daily oral dose of toremifene, 18 men with high-grade PIN underwent a repeat prostate biopsy. The prostate biopsy specimens showed significantly less high-grade PIN than historical controls. This trial provided the proof-of-concept support behind a currently open 485 patient placebo controlled, randomized dose finding phase IIb/III clinical trial 
(Price et al., 2006). This trial is investigating the efficacy of toremifene in reducing prostate cancer incidence in men with high-grade PIN. Men with high-grade PIN are treated for 12 months with placebo or toremifene and will undergo a repeat prostate biopsy at 6 and 12 months (the trial details are available at http://www.gtxinc.com/tech/clinical.htm). In addition, the National Cancer Institute is evaluating the effects of toremifene versus placebo in men with prostate cancer prior to radical prostatectomy. The objective of this phase II clinical trial is to evaluate the effects of a toremifene on biomarkers of prostate cancer. The trial details are available at http:/ / www.cancer.gov/search/ViewClinicalTrials.

\section{Difluoromethyl ornithine (DFMO)}

DFMO is an irreversible inhibitor of ornithine decarcoxylase involved in the synthesis of polyamines; it possesses cytostatic and cytotoxic effects (Messing et al., 1999). At the clinical level, interest in exploring DFMO as a chemoprevention agent for prostate cancer has recently increased as the administration of DFMO at $0.5 \mathrm{~g} / \mathrm{m} 2$ daily for 4 weeks to men scheduled for surgical interventions to treat either prostatic hyperplasia or neoplasia resulted in reduction of polyamine pools, including spermine (Simoneau et al., 2001). These results confirm that DFMO reaches the target tissue and hence may warrant further study as a possible chemopreventive agent for prostate cancer.

\section{Selective COX-2 inhibitors}

Inhibition of COX-2 expression blocks its pro-inflammatory effects, reduces expression of androgen receptors and androgen inducible genes and promotes apoptosis in prostate cancer cells. Selective COX-2 expression has been observed in high-grade PIN, a putative precursor of prostate cancer, suggesting a role early in carcinogenesis (Hussain et al., 2003). These results support the hypothesis that inhibition of COX-2 may be an effective preventive strategy for prostate cancers; however, an industry-sponsored large-scale trial of rofecoxib was closed after the drug was withdrawn from the market because of concerns over its cardiovascular safety.

\section{Selenium}

Many of the cellular processes and molecular markers shown to be modified by selenium play key roles in prostate cancer progression. Two clinical trials are examining the role of selenium in other groups of high-risk individuals: men who have had negative prostate biopsies and men with HGPIN. The Negative Biopsy study, which includes men who have had at least one negative sextant prostate biopsy, will be using selenium supplementation in the form of selenium yeast, SeY (200 or $400 \mu \mathrm{g}$ ) (Marshall, 2001). The high-grade PIN study will determine the incidence of prostate cancer in men with biopsy-proven high grade intraepithelial neoplasia supplemented daily with $200 \mu \mathrm{g}$ selenomethionine (Marshall, 2001). The results of these studies will be critical in defining a role for intervention with selenium in high-risk individuals, for whom there is no current treatment.

\section{Bicalutamide}

Intermittent (weekly), low-dose bicalutamide on prostate morphology revealed a tendency to a favorable modulation of high-risk proliferative lesions such as HGPIN. Namely, HGPIN status improved in $26 \%$ of treated subjects as compared with $4 \%$ of subjects in the notreatment arm. These findings must be interpreted with extreme caution due to the inherent 
limitations of prostate sampling with needle biopsy. However, our analysis including all changes in HGPIN status (i.e., both HGPIN resolution and HGPIN development after 6 months of treatment) may account, at least in part, for sampling errors, supporting the worth of our findings although they derive from a post hoc analysis. The $28 \%$ incidence of HGPIN found in our study was unusually high compared with that reported in the general population, which ranges from $0.7 \%$ to $25 \%$ in noncancerous prostate biopsies (Bubendorf et al., 1998). HGPIN incidence increases with age and is higher in men seen in clinical practice compared with men participating in screening programs (Bostwick and Qian, 2004). As most subjects in our study were in their seventies and as all were urological practice outpatients, this could partly explain our findings. Moreover, whereas HGPIN by itself does not seem to increase PSA (Bostwick and Qian, 2004), the incidence of HGPIN in homogeneous cohorts of men with elevated PSA is largely unknown. Once-a-week administration of bicalutamide in men at risk for prostate cancer is feasible and reasonably safe. This finding, coupled with the encouraging signal of activity emerging from the analysis of HG-PIN changes, supports further studies of this schedule at the lowest dose for prostate cancer prevention in men at high risk despite the negative primary end-point findings on Ki-67 (Zandari et al., 2009).

\section{Nutraceuticals and Micronutrients}

Nutraceutical compounds most commonly show antioxidant properties combined with other anti-neoplastic actions (Syed et al., 2008). Table 3 presents the most notable nutraceutical compounds examined in prostate cancer prevention, including vitamin D, vitamin E, selenium, lycopene, soy, and green tea (Trottier et al., 2010a \& b).

\begin{tabular}{|c|c|c|c|c|c|}
\hline Compound & Origin & Proposed mechanism & Sirength of evidence & Outcomes & Selected references \\
\hline Vitamin D (calcitriol) & Sunlight, meats, fish & $\begin{array}{l}\text { Vitamin D receptor activation: } \\
\text { cancer homeostasis, cell proliferation } \\
\text { and differentiation }\end{array}$ & $\begin{array}{l}\text { Case-control and } \\
\text { cohort studies }\end{array}$ & $\begin{array}{l}\text { Conflicting when levels are normal; } \\
\text { modest evidence when levels are low }\end{array}$ & $\begin{array}{l}\text { Trottier et al., } 2010 \\
\text { Schwart et al., } 2006\end{array}$ \\
\hline $\begin{array}{l}\text { Vitamin E } \\
\text { (tocopherols and } \\
\text { tocotrienols) }\end{array}$ & $\begin{array}{l}\text { Nuts, vegetable oils, } \\
\text { palm oil, oats, rye, } \\
\text { wheat, rice bran }\end{array}$ & Antioxidant, proapoptotic & $\begin{array}{l}\text { Cohort studies, } \\
2 \text { RCTS }^{\mathrm{a}}\end{array}$ & $\begin{array}{l}\text { No difference from placebo } \\
\qquad \text { in RCTS }\end{array}$ & $\begin{array}{l}\text { Gaziano et al., } 2009 \\
\text { Lippman et al., } 2009\end{array}$ \\
\hline Lycopene & Tomatoes & Carotenoid antioxidant & $\begin{array}{l}\text { Case-control and } \\
\text { cohort studies, } \\
\text { meta-analysis }\end{array}$ & $\begin{array}{l}\text { Positive meta-analysis, } \\
\text { but negative results from } \\
\text { the plo0 screening trial }\end{array}$ & $\begin{array}{l}\text { Etminan et al., } 2004 \\
\text { Kirsh et al., } 2006 \\
\text { Peters et al., } 2007\end{array}$ \\
\hline Soy and isoflavanoids & Soybeans & $\begin{array}{l}\text { Phytoestrogens and tyrosine kinase } \\
\text { inhibition causing apoptosis, limited } \\
\text { cell growth, reduced inflammation }\end{array}$ & $\begin{array}{l}\text { Case-control and } \\
\text { cohort studies, } \\
\text { meta-analysis }\end{array}$ & $\begin{array}{l}\text { Positive effect noted with } \\
\text { non-fermented soy and mainly } \\
\text { in non-Westem men }\end{array}$ & $\begin{array}{c}\text { Yan and Spitznagel, } \\
2009\end{array}$ \\
\hline Green tea & $\begin{array}{l}\text { Camellia sinensis } \\
\text { plant }\end{array}$ & $\begin{array}{l}\text { E000 is the likely active ingredient: } \\
\text { antioxidant polyphenol } \\
\text { and } 5 \text { ARI activity }\end{array}$ & $\begin{array}{l}\text { Case-control and } \\
\text { cohort studies, } \\
1 \text { RCT }\end{array}$ & $\begin{array}{l}\text { Conflicting for overall Pca diagnosis; } \\
\text { possible positive effect on } \\
\text { advanced pca diagnosis }\end{array}$ & $\begin{array}{c}\text { Kurahashi et al., } 2008 \\
\text { Brausi et al., } 2008\end{array}$ \\
\hline
\end{tabular}

"sELECT (Selenium and Vitamin E Cancer Prevention Trial) and Physician's Health Study II.

$\mathrm{RCT}=$ randomized control trial; PLCO = Prostate, Lung, Colorectal, and Ovarian Cancer; $E G 00=$ epigallocatechin-3-gallate; 5 ARI $=50$-reductase inhibitor; $\mathrm{PCa}=$ prostate cancer.

Table 3. Primary prostate cancer prevention with selected nutraceutical (Trottier et al., 2010) 


\section{Signal anomalies of human prostate cancer}

Prostatic intraepithelial neoplasia (PIN) lesions could be described as low grade (LG) or high grade (HG) and it is widely perceived that HGPIN is a precursor of prostatic adenocarcinoma (Isaacs et al., 2002). Since the initial growth of prostate tumor or cancer is dependent on androgens, hormone therapy in the form of medical or surgical castration constitutes a common approach for systemic treatment. However over a period of time, most cancer will develop androgen-independence, thereby making the continued androgen deprivation therapy ineffective (Taplin and Balk, 2004). While the mechanisms that drive the genesis of subclinical, microscopic PIN lesions, their progression to invasive cancer and androgen independence remain largely unknown and evidence collected in recent years point to certain molecular aberrations that pave the path of disease progression.

For example, anomalies in specific signaling molecules, including extracellular growth factors, protein tyrosine kinase cell surface receptors, intracellular transcription factors, nuclear factors and their ligands, growth suppressors, cell cycle regulators and others have indicated in some prostate carcinomas (Abate Shen and Shen, 2000; Gao and Isaacs, 2000; Roy-Burman et al., 2004)

There is currently a strong focus on the genetic alterations or aberrations in gene expression that are frequently encountered in human prostate cancer in the design of mouse models. Although both men and mice harbour functionally equivalent prostate glands, there are similarities as well as differences in the anatomy and histology of the prostate in the two species. Similar epithelial cell types namely secretory, basal and neuroendocrine are found in both mouse and human prostate, although their proportions vary. While human prostate has a robust fibromuscular stroma, the mouse contains a modest stromal component. Anatomically the human prostate gland is a single, alobular structure with central, peripheral and transitional zones. In contrast, the mouse prostate is composed of four paired lobes namely anterior (AP), dorsal (DP), lateral (LP) and ventral (VP) prostate. Since DP and LP share a ductal system they are often dissected together and referred to as the dorsolateral prostate (DLP). The mouse DLP is perceived to be the most similar to the human peripheral zone in which the majority of clinically diagnosed prostate cancers are found. The mouse VP does not appear to have a human homologue and the human transitional zone does not have a murine homologue. The transitional zone constitutes a site where human nodular hyperplasia (BPH) is commonly seen. The mouse AP is analogous to the human central zone, which only infrequently represents a site of neoplasia in humans (Roy-Burman et al., 2004).

\section{Cell surface signaling molecules}

Signaling interactions between various extracellular growth factors and the corresponding cell surface receptors converge to determine the fate of the cell with respect to proliferation, survival or death. In this context, dysregulation of several growth factors or their receptors has been implicated in prostate tumorigenesis. A number of transgenic mouse lines have been produced in which genes that are known to be overexpressed in human prostate cancer are targets. The survival factor, insulin like growth factor-I (IGF-I) which is generally overexpressed in human prostate and which may potentially be a good tumor marker in 
prostate cancer was a target in a transgenic line (Woodson et al., 2003). Its expression in the mouse tissues was designed by using the bovine keratin 5 promoter (Di Giovanni et al., 2000). These mice develop squamous papillomas some of which progress to carcinomas of the skin. The increased IGF I levels also lead to pathologic changes in the prostate and in other male accessory glands of these animals (Di Giovanni et al., 2000a). The severity of the lesions in the prostate ranges from PIN to carcinoma in Situ as well as tumors with neuroendocrine differentiation.

\section{Fibroblast Growth Factors (FGFs)}

The FGF family of heparin binding proteins is intercellular signaling molecules of which atleast 23 different members (FGF-1 - FGF-23) have been identified to date. FGF proteins are generally secreted and their effects are mediated by a complex system of FGF receptor (FGFR) tyrosine kinases, either through autocrine or paracrine mechanisms, or both (Wilkie et al., 1995; McKeehan et al., 1998). While dysregulation of several FGFs has been described in prostate development and tumorigenesis, two members, FGF 7 and FGF 8 have been further pursued through mouse modeling experiments (Djakiew, 2000; Thomson, 2001).

FGF $8 \mathrm{~b}$ has been demonstrated to possess the most transforming and tumorigenic potential (Daphna-Iken et al., 1998). While expression of FGF $8 \mathrm{~b}$ appears to represent the primary species in prostatic epithelium, its expression is practically undetected in the stromal component of prostate cancer (Valve et al., 2001). Increased expression of FGF $8 \mathrm{~b}$ in prostatic lesions beginning from PIN to adenocarcinoma and its persistence in androgen independent disease has been described. The overexpression of FGF8b in prostate cancer cells has been shown to increase proliferative and invasive properties of the affected cells directly and proliferation of prostatic stromal cells indirectly (Song et al., 2000). Consistent with these results antisense down regulation of FGF8b mRNA reduces the growth rate, inhibits cologenic activity and decreases in vivo tumorigenicity of prostate tumor cells (RudraGanguly et al., 1998). FGF 8 expressions in prostate cancer is regulated by the androgen receptor at the transcriptional level and that FGF 8 is angiogenic further enhance the biological relevance of the factor in prostate cancer.

Prostatic hyperplasia appears in the LP and VP in some FGF $8 \mathrm{~b}$ transgenic animals as early as 2 to 3 months and in DP and AP between 6 to 16 months. LGPIN lesions manifest from 5 to 7 months. $100 \%$ of the mice display multifocal prostatic epithelial hyperplasia during the first 14 months with 35\% also having areas of LGPIN. In subsequent months (15 to 24 months) the profile changes to a higher incidence of LGPIN (66\%) along with HGPIN (51\%). Ocassionally HGPIN lesions resemble the histopathology of human prostatic carcinoma in situ.

\section{P27kip, regulator of cyclin-cdk activity}

Activation of AKT through deregulated phosphatidylinositol 3- kinase (PI3K) signaling resulting from genetic inactivation of phosphatase and tensin homolog (PTEN), mutational activation of PI3K, or the activation of upstream oncogenic tyrosine kinases is a frequent molecular event in human cancer (Brugge et al., 2007; Lee et al., 2007). Transgenic expression 
of activated AKT1 in the murine prostate induces prostatic intraepithelial neoplasia (PIN) that does not progress to invasive prostate cancer. In human epithelial cancers, reduced levels of p27Kip1 expression are frequently observed (Slingerland and Pagano, 2000) and are correlated with tumor progression and poor survival (Loda et al., 1997; Porter et al., 1997; Yang et al., 1998). p27Kip1 functions primarily as a negative regulator of cyclin-CDK activity and thus likely participates in tumor suppression by inhibiting cell-cycle progression (Chu et al., 2008). Targeted disruption of p27Kip1 (Cdkn1b_/_) in mice leads to prostatic hyperplasia (Cordon-Cardo et al., 1998) and development of pituitary adenomas (Fero et al., 1996, 1998) as the mice age. However, Cdkn1b_/- mice do not typically develop other spontaneous tumors (Fero et al., 1996; Kiyokawa et al., 1996; Nakayama et al., 1996).

In many human cancer cells, oncogene-induced senescence (OIS) is associated with known tumor suppressor pathways such as p53, VHL, and Rb (Serrano et al., 1997; Young et al., 2008). It has been reported that OIS occurs in many human and mouse precursors of cancer and that this phenomenon can be reversed by the inactivation of tumor suppressor pathways (Braig et al., 2005; Chen et al., 2005; Collado et al., 2005; Michaloglou et al., 2005). Majumder et al. investigated the role of p27Kip1 in tumor suppression in prostate cancer using both genetically engineered mice and human prostate samples (Majumder et al., 2008). They have identified a relationship among senescence induction, p27Kip1 expression, and PIN that supports the notion that p27Kip1 induction in the context of early neoplastic lesions may represent a preinvasive checkpoint linked to cellular senescence.

Importantly, is study is highly relevant to human prostate cancer (Majumder et al., 2008). Indeed, we show that p27Kip1 is overexpressed in human PIN not associated with invasive cancer, presumably representing the earliest phase of neoplastic transformation. In contrast, PIN adjacent to invasive cancer, where checkpoint loss may have already occurred, is associated with low levels of $\mathrm{p} 2 \mathrm{KKip}^{1}$. The role of $\mathrm{p} 2 \mathrm{KKip}^{\mathrm{K}}$ in this process is further supported by a body of data showing that loss of p27Kip1 is commonly found in human cancers (Chu et al., 2008) and that invasive tumor cells specifically degrade p27Kip1. This in turn results in increased CDK2 activity (Loda et al., 1997).

As many as $30 \%$ of men with a diagnosis of PIN on biopsy are subsequently found to harbor an invasive prostatic adenocarcinoma on repeat biopsy (Gokden et al., 2005). Thus the CDK inhibitors might have utility in preventing cancer progression from in situ dysplasia to invasion.

\section{Conclusions}

High-grade PIN is the most likely precursor of prostatic adenocarcinoma, according to virtually all available evidence. PIN is associated with progressive abnormalities of phenotype and genotype that are intermediate between normal prostatic epithelium and cancer, indicating impairment of cell differentiation and regulatory control with advancing stages of prostatic carcinogenesis. There is progressive loss of some markers of secretory differentiation, whereas other markers show progressive increase. The clinical importance of recognizing PIN is based on its strong association with prostatic carcinoma. PIN has a high predictive value as a marker for adenocarcinoma, and its identification in biopsy specimens of the prostate warrants further search for concurrent invasive carcinoma. Studies to date 
have not determined whether PIN remains stable, regresses, or progresses, although the implication is that it can progress. Chemoprevention of early stage of prostate cancer, PIN may be useful strategy in the prostate cancer prevention.

\section{Acknowledgements}

The financial assistance provided by University of Madras as UWPFEP Fellowship to one of the authors Mr. A. Arunkumar and Council of Scientific and Industrial Research (CSIR), India, in the form of CSIR-SRF to Ms. S. Banudevi are gratefully acknowledged.

\section{References}

Abate Shen C, Shen MM. Molecular genetics of prostate cancer. Genes Dev. 2000; 14:24102434.

Abrahams NA, Ormsby AH, Brainard J. Validation of cytokeratin 5/6 as an effective substitute for keratin 903 in the differentiation of benign from malignant glands in prostate needle biopsies. Histopathology 2002; 41:35-41.

Allam CK, Bostwick DG, Hayes JA, et al. Interobserver variability in the diagnosis of high grade prostatic intraepithelial neoplasia and adenocarcinoma. Mod Pathol. 1996; 9:742-751.

Al-Maghrabi J, Vorobyova L, Toi A, et al. Identification of numerical chromosomal changes detected by interphase fluorescence in situ hybridization in high-grade prostate intraepithelial neoplasia as a predictor of carcinoma. Arch Pathol Lab Med. 2002; 126:165-169.

Amin MB, Ro JY, Ayala AG. Ideas in pathology: putative precursor lesions of prostatic adenocarcinoma: fact or fiction? Mod Pathol. 1993; 6:476-483.

Amin MB, Schultz DS, Zarbo RJ. Computerized static DNA ploidy analysis of prostatic intraepithelial neoplasia. Arch Pathol Lab Med. 1994; 118:260-264.

Aquilina JW, Lipsky JJ, Bostwick DG: Androgen deprivation as a strategy for prostate cancer chemoprevention. J Natl Cancer Inst. 1997; 89:689-696.

Armas OA, Melamed A, Aprikian A, et al. Effect of preoperative androgen deprivation therapy in prostatic carcinoma [abstract]. Lab Invest. 1993; 68:55A.

Arunkumar A, Vijayababu MR, Venkataraman P, Senthilkumar K, Arunakaran J. Chemoprevention of rat prostate carcinogenesis by diallyl disulfide, an organosulfur compound of garlic. Biol Pharm Bull. 2006; 29:375-379.

Banudevi S, Elumalai P, Arunkumar R, Senthilkumar K, Gunadharini DN, Sharmila G, Arunakaran J. Chemopreventive effects of zinc on N-methyl-N-nitrosourea and testosterone induced prostatic intraepithelial neoplasia in the dorsolateral prostate of male Sprague-Dawley rats. J Cancer Res Clin Oncol. 2011a; 137:677-686.

Banudevi S, Elumalai P, Sharmila G, Arunkumar R, Senthilkumar K, Arunakaran J. Protective effects of zinc on prostate carcinogenesis induced by N-methyl-Nnitrosourea and testosterone in adult male Sprague-Dawley rats. Exp Biol Med. 2011b; in press.

Bethesda Md. Prostatic intraepithelial neoplasia: significance and correlation with prostatespecific antigen and transrectal ultrasound. Proceedings of a workshop of the 
National Prostate Cancer Detection Project; March 13, 1989; Bethesda, Md. Urol. 1989; 34:2-69.

Bettuzzi S, Brausi M, Rizzi F, Castagnetti G, Peracchia G, Corti A. Chemoprevention of human prostate cancer by oral administration of greentea catechins in volunteers with high-grade prostate intraepithelial neoplasia: a preliminary report from a oneyear proof-of-principle study. Cancer Res. 2006; 6:1234-1240.

Bosland MC, Prinsen MK. Induction of dorsolateral prostate adenoma carcinomas and other accessory sex gland lesions in male Wistar rats by N-methyl-N-nitrosourea, 7,12dimethylbenz(a) anthracene, and 3,2'-dimethyl-4-aminobiphenyl after sequential treatment with cyproterone acetate and testosterone propionate. Cancer Res. 1990; 50:691-699.

Bostwick DG, Amin MB, Dundore P, et al.: Architectural patterns of high-grade prostatic intraepithelial neoplasia. Hum Pathol. 1993; 24:298-310.

Bostwick DG, Amin MB. Prostate and seminal vesicles. In: Damjanov I, Linder J (eds.), Anderson's pathology, 10th edn, Vol. II, Chapter.67. St. Louis: Mosby, 1996, 2166230.

Bostwick DG, Brawer MK. Prostatic intra-epithelial neoplasia and early invasion in prostate cancer. Cancer 1987; 59:788-794.

Bostwick DG, Burke HB, Wheeler TM, et al.: The most promising surrogate endpoint biomarkers for screening candidate chemopreventive compounds for prostatic adenocarcinoma in short-term phase II clinical trials. J Cell Biochem. 1994b; 19 (suppl):283-289.

Bostwick DG, Dousa M, Crawford, et al. Neuroendocrine differentiation in prostatic intraepithelial neoplasia and adenocarcinoma. Am J Surg Pathol. 1994a; 18:12401246.

Bostwick DG, Qian J, Frankel K. The incidence of high-grade prostatic intraepithelial neoplasia in needle biopsies. J Urol. 1995; 154:1791-1794.

Bostwick DG, Qian J. High-grade prostatic intraepithelial neoplasia. Mod Pathol. 2004; 17(3):360-379.

Bostwick DG. Phase II efficacy trials for chemoprevention in patients with PIN: strategies with androgen deprivation therapy. In: Crawford ED ( ed.), Proceedings of 7th International Prostate Cancer Update. Beaver Creek, Colorado, 22-26 January 1997.Pp 485-490.

Bostwick DG. Prospective origins of prostate carcinoma. Prostatic intraepithelial neoplasia and atypical adenomatus hyperplasia. Cancer 1996; 78:330.

Bostwick DG. Prostatic intraepithelial Neoplasia (PIN). Urol. 1989; 34:16-22.

Bostwick DG. Target populations and strategies for chemoprevention trials of prostate cancer. J Cell Biochem. 1994; 19(suppl): 191-196.

Braig M, Lee S, Loddenkemper C, Rudolph C, Peters AH, SchlegelbergerB, Stein H, Dorken $B$, Jenuwein T, Schmitt CA. Oncogene- induced senescence as an initial barrier in lymphoma development. Nature 2005; 436:660-665

Brawer MK, Peehl DM, Stamey TA, Bostwick DG. Keratin immunoreactivity in the benign and neoplastic human prostate. Cancer Res. 1985; 45:3663- 3667. 
Brawer MK. Prostatic intraepithelial neoplasia: an overview. Rev Urol. 2005; 7(suppl 3):S11S18.

Brugge J, Hung MC, Mills GB. A new mutational AKT activation in the PI3K pathway. Cancer Cell 2007; 12:104-107.

Bubendorf L, Tapia C, Gasser TC, et al. Ki67 labeling index in core needle biopsies independently predicts tumor-specific survival in prostate cancer. Hum Pathol.1998; 29:949-54.

Chen Z, Trotman LC, Shaffer D, Lin HK, Dotan ZA, Niki M, Koutcher JA, Scher HI, Ludwig $\mathrm{T}$, Gerald W, et al. Crucial role of p53-dependent cellular senescence in suppression of Pten-deficient tumorigenesis. Nature 2005; 436:725-730.

Choan E, Segal R, Jonker D, Malone S, Reaume N, Eapen L, Gallant V.2005. A prospective clinical trial of green tea for hormone refractory prostatecancer: an evaluation of the complementary/alternative therapy approach.Urol Oncol. 2005; 23:108-113.

Christov KT, Moon RC, Lantvit DD, Boone CW, Steele VE, Lubet RA, Kelloff GJ, Pezzuto JM. Cancer Res. 2002; 62:5178-5182.

Chu IM, Hengst L, Slingerland JM. The Cdk inhibitor p27 in human cancer: prognostic potential and relevance to anticancer therapy. Nat Rev Cancer 2008; 8:253-267.

Collado M, Gil J, Efeyan A, Guerra C, Schuhmacher AJ, Barradas M, Benguria A, Zaballos A, Flores JM, Barbacid, M, et al. Tumour biology: senescence in premalignant tumours. Nature 2005: 436: 642.

Cordon-Cardo C, Koff A, Drobnjak M, Capodieci P, Osman I, Millard SS, Gaudin PB, Fazzari M, Zhang ZF, Massague J, Scher HI. Distinct altered patterns of p27KIP1 gene expression in benign prostatic hyperplasia and prostatic carcinoma. $J$ Natl Cancer Inst. 1998; 90:1284-1291.

Daphna-Iken D, Shankar DB, Lawshe A, Ornitz DM, Shackleford GM, MacArthur CA. FGF8 isoforms differ in NIH3T3 cell transforming potential. Cell Growth Differ. 1998; 6:817-825.

De La Torre M, Haggman M, Brandstedt S, Busch C. Prostatic intraepithelial neoplasia and invasive carcinoma in total prostatectomy speciemens: distribution, volumes and DNA ploidy. Br J Urol. 1993; 72:207.

Deschenes J, Weidner N. Nucleolar organizer regions (NOR) in hyperplastic and neoplastic prostate disease. Am J Surg Pathol. 1990; 14:1148-1155.

Di Giovanni J, Boe DK, Wilker E et al. Constitutive expression of insulin like growth factor 1 in epidermal basal cells of transgenic mice leads to spontaneous tumor promotion. Cancer Res. 2000a; 63:3991-3994.

Di Giovanni J, Kiguchi K, Frijhoft A et al. Deregulated expression of IGF I in prostate epithelium leads to neoplasia in transgenic mice. Cancer Res. 2000b; 60:1561-1570.

Di Sant' Agnese PA. Neuroendocrine differentiation in the precursor of prostate cancer. Eur Urol. 1996; 30: 185-190.

Djakiew D. Dysregulated expression of growth factors and their receptors in the development of prostate cancer. Prostate 2000; 42: 150-160.

Drago JR, Mostofi FK, Lee F. Introductory remarks and workshop summary. Urol. 1989; 34:2-3. 
Emmert-Buck MR,Vocke CD, Pozzatt RO, et al. Allelic loss of chromosome 8p12-21 in microdissected prostatic intraepithelial neoplasia. Cancer Res. 1995; 55:2959-2962.

Epstein JI. Adenosis (atypical adenomatous hyperplasia): histopathology and relationship to carcinoma. Path Res Pathol. 1994; 191:888.

Eschenbach AC. The biologic dilemma of early carcinoma of the prostate. Cancer 1996; 78: 326.

Ferguson J, Zincke H, Ellison E, et al. Decrease of prostatic intraepithelial neoplasia (PIN) following androgen deprivation therapy in patients with stage T3 carcinoma treated by radical prostatectomy. Urol. 1994; 44:91-95.

Fero ML, Randel E, Gurley KE, Roberts JM, Kemp CJ. The murine gene p27Kip1 is haploinsufficient for tumour suppression. Nature 1998; 396:177-180.

Fero ML, Rivkin M, Tasch M, Porter P, Carow CE, Firpo E, Polyak K, Tsai LH, Broudy V, Perlmutter RM, et al. A syndrome of multiorgan hyperplasia with features of gigantism, tumorigenesis, and female sterility in p27(Kip1)-deficient mice. Cell 1996; 85: 733-744.

Gao A, Isaccs JT. The molecular basis of prostate carcinogenesis. In: Coleman WB, Tsongalis GJ (eds.), Molecular basis of human cancer, The Humana Press. Inc., Totowa NJ, 2000. Pp 365-379.

Garabedian EM, Humphrey PA, Gordon JI. A transgenic mouse model of metastatic prostate cancer originating from neuroendocrine cells. Proc Natl Acad Sci USA 1998; 95:15382-15387.

Gaudin PB, Sesterhenn IA, Wojno K, Mostofi FK, Epstein JI. Incidence and clinical significance of high grade prostatic intraepithelial neoplasia in TURP specimens. Urol. 1997; 49:558-563.

Gokden N, Roehl KA, Catalona WJ, Humphrey PA. Highgrade prostatic intraepithelial neoplasia in needle biopsy as risk factor for detection of adenocarcinoma: current level of risk in screening population. Urol. 2005; 65:538-542.

Hussain T, Gupta S, Mukhtar H. Cyclooxygenase-2 and prostate carcinogenesis. Cancer Lett. 2003; 191:125-135.

Ingles SA, Ross RK, Yu MC, et al. Association of prostate cancer risk with genetic polymorphisms in vitamin D receptor and androgen receptor. J Natl Cancer Inst. 1997; 89:166-170.

Isaacs W, De Marzo A, Nelson WG. Focus on prostate cancer. Cancer Cell 2002; 2:113-116.

Jatoi A, Ellison N, Burch PA, Sloan JA, Dakhil SR, Novotny P, TanW, Fitch TR, Rowland KM, Young CY, Flynn PJ. A phase IItrial of green tea in the treatment of patients with androgen independent metastatic prostate carcinoma. Cancer 2003; 97:14421446.

Jemal A, Siegel R, Ward E, Murray T, Xu J, Thun, MJ. Cancer statistics, 2010. CA. Cancer J Clin. 2010; 57:43-66.

Jian L, Xie LP, Lee AH, Binns CW. Protective effect of green tea against prostate cancer: a case-control study in southeast China. Int J Cancer 2004; 108:130-135.

Jones EC, Young RH. The differential diagnosis of prostatic carcinoma. Its distinction from premalignant and pseudocarcinomatous lesions of the prostate gland. Am J Clin Pathol. 1994; 101:148. 
Kadomatsu K, Anzano MA, Slayter MV, et al. Expression of sulfated glycoprotein 2 is associated with carcinogenesis induced by $\mathrm{N}$-nitroso-M-methylurea in rat prostate and seminal vesicle. Cancer Res. 1993; 53:1480-1483.

Kasper S, Sheppard PC, Yan Y, et al.: Development, preogression, and androgendependence of prostate tumors in probasin-large $\mathrm{T}$ antigen transgenic mice: A model for prostate cancer. Lab Invest. 1998; 78:319-333.

Kellof GJ. Chemoprevention strategies for prostate cancer. In: Crawford ED, (ed.), Proceedings of 7th International Prostate Cancer Update. Beaver Creek, Colorado, 22-26 January 1997.Pp 134-135.

Kelloff GJ, Hawk ET, Crowell JA, et al. Strategies for identification and clinical evaluation of promising chemoprevention agents. Oncology 1996; 10:1471-1481.

Kiyokawa H, Kineman RD, Manova-Todorova KO, Soares VC, Hoffman ES, Ono M, Khanam D, Hayday AC, Frohman LA, Koff A. Enhanced growth of mice lacking the cyclin-dependent kinase inhibitor function of p27(Kip1). Cell 1996; 85:721-732.

Langer JE, Rovner ES, Coleman BG, et al.: Strategy for repeat biopsy of patients with prostatic intraepithelial neoplasia detected by prostate needle biopsy. J Urol. 1996; 155:228-231.

Lee JY, Engelman JA, Cantley LC.Biochemistry. PI3K charges ahead. Science 2007; 317:206207.

Lipski B, Garcia R, Brawer M. Prostatic intraepithelial neoplasia: significance and management. Semin Urol Oncol. 1996; 14:149-155.

Loda M, Cukor B, Tam SW, Lavin P, Fiorentino M, Draetta GF, Jessup JM, Pagano M. Increased proteasome-dependent degradation of the cyclin-dependent kinase inhibitor p27 in aggressive colorectal carcinomas. Nat Med.1997; 3:231-234.

Macoska JA, Trybus TM, Benson PD, et al. Evidence for three tumor suppressor gene loci on chromosome 8p in human prostate cancer. Cancer Res. 1995; 55:5390-5395.

Majumder PK, Grisanzio C, O'Connell F, Barry M, Brito JM, Xu Q, Guney I, et al. A Prostatic Intraepithelial Neoplasia-Dependent p27Kip1 Checkpoint Induces Senescence and Inhibits Cell Proliferation and Cancer Progression. Cancer Cell 2008; 14:146-155.

Mashall JR. Larry Clark's Legacy: Randomized, controlled, selenium-based, prostate cancer chemopreventiontrials. Nutr Cancer 2001; 40:74-77.

Mc Keehan WL, Wang F, Kan M. The heparin sulfate- fibroblast growth factor family: diversity of structure. Prog Nucleic Acid Res Mol Biol. 1998; 59 135-176.

McCormick DL. Chemoprevention of hormone-dependent prostate cancer in the WistarUnilever rat. In: Schulman C, Kelloff G (eds.), Proceedings of the International Symposium "Strategies for the chemoprevention of prostate cancer". Brussels, 30-31 October 1998. Pp 38.

McNeal JE, Alroy J, Leav I, Redwine EA, Freiha FS, Stamey TA. Immunohistochemical evidence for impaired cell differentiation in the premalignant phase of prostate carcinogenesis. Am J Clin Pathol. 1988b;90:23-32.

McNeal JE, Bostwick DG. Intraductal dysplasia: a premalignant lesion of the prostate. Hum Pathol. 1986; 17:64-71. 
McNeal JE, Leav I, Alroy J. Differential lectin staining of central and peripheral zones of the prostate and alterations in dysplasia. Am J Clin Pathol. 1988a; 89:41-48.

McNeal JE. Morphogenesis of prostate carcinoma. Cancer 1965; 18:1659-66.

McNeal JE. Origin and development of carcinoma in the prostate. Cancer. 1969; 23:24-34.

McNeal JE. Significance of duct-acinar dysplasia in prostatic carcinogenesis. Prostate 1988; 13:91-102.

Melissari M, Lopez-Beltran A, Mazzucchelli R, Froio E, Bostwick DG, Montironi R. High grade prostatic intraepithelial neoplasia with squamous differentiation. J Clin Pathol. 2006; 59:437-439.

Messing EM, Love RR, Tutsch KD, Verma AK, Douglas J, Pomplun M, Simsiman R, Wilding G. Low-dose difluoromethylornithine and polyamine levels in human prostate tissue. J Natl Cancer Inst. 1999; 91:1416-1417.

Michaloglou C, Vredeveld LC, Soengas MS, Denoyelle C, Kuilman T,van der Horst CM, Majoor DM, Shay JW, Mooi WJ, Peeper DS. BRAFE600-associated senescence-like cell cycle arrest of human naevi. Nature 2005; 436:720-724.

Montironi R, Diamanti L, Thompson D, et al. Analysis of the capillary architecture in the precursors of prostate cancer: recent findings and new concepts. Eur Urol. 1996; 30:191-200.

Montironi R, Galluzzi CM, Scarpelli M, et al. Quantitative characterization of the frequency and location of cell proliferation and death in prostate pathology. J Cell Biochem. 1994; 19(suppl):238-45.

Morote J, Fernandez S, Alan L, Iglesias C, Planas J, Reventos J, Cajal SR, Paciucci R, and de Torres IM. PTOV1 Expression Predicts Prostate Cancer in Men with Isolated HighGrade Prostatic Intraepithelial Neoplasia in Needle Biopsy. Clin Cancer Res. 2008; 14: 2617-2622.

Nagle RB, Brawer MK, Kittelson J. Phenotypic relationships of prostatic intraepithelial neoplasia to invasive prostatic carcinoma. Am J Pathol. 1991; 138: 119-128.

Nakayama K, Ishida N, Shirane M, Inomata A, Inoue T, Shishido N, Horii I, Loh DY. Mice lacking p27(Kip1) display increased body size, multiple organ hyperplasia, retinal dysplasia, and pituitary tumors. Cell 1996; 85:707-720.

Nelson PS, Gleason TP, Brawer MK. Chemoprevention for prostatic intraepithelial neoplasia. Eur Urol. 1996; 30:269- 278.

Pacelli A, Bostwick DG. Clinical significance of high-grade prostatic intraepithelial neoplasia in transurethral resection specimens. Urol. 1997; 50:355-359.

Perlman EJ, Epstein JI. Blood group antigen expression in dysplasia and adenocarcinoma of the prostate. Am J Surg Pathol. 1990; 14:810-818.

Pollard M. The Lobund-Wistar rat model of prostate cancer. J Cell Biochem. 1992; 16(suppl):84-88.

Porter PL, Malone KE, Heagerty PJ, Alexander GM, Gatti LA, Firpo EJ, Daling JR, Roberts JM.. Expression of cell-cycle regulators p27Kip1 and cyclin E, alone and in combination, correlate with survival in young breast cancer patients. Nat Med. 1997; 3:222-225.

Price D, Stein B, Sieber P, Tutrone R, Bailen J, Goluboff E, Burzon D,Bostwick D, Steiner M. Toremifene for the prevention of prostate cancer in men with high grade prostatic 
intraepithelial neoplasia: results of a double-blind, placebo controlled, phase IIB clinical trial. J Urol. 2006; 176:965-970.

Qian J, Jenkins RB, Bostwick DG. Genetic and chromosomal alterations in prostatic intraepithelial neoplasia and carcinoma detected by fluorescence in situ hybridization. Eur Urol. 1999; 35:479-483.

Qian J, Wollan P, Bostwick DG. The extent and multicentricity of high grade prostatic intraepithelial neoplasia in clinically localized prostatic adenocarcinoma. Hum Pathol. 1997; 28:143-148.

Roy-Burman P, Wu H, Powell WC, Hagenkord J, Cohen MB. Genetically7 defined mouse models that mimic natural aspects of human prostate cancer development. Endocrine Relat Cancer 2004; 11:225-254.

Rudra-Garsguly N, Zheng J, Hoang AT, Roy-Burman P. Down regulation of human FGF 8 activity by antisense constructs in murine fibroblastic and human prostatic carcinoma cell systems. Oncogene 1998; 16:1487-1492.

Sakr WA, Haas GP, Cassin BF, Pontes JE, Crissman JD. The frequency of carcinoma and intraepithelial neoplasia of the prostate in young male patients. Br J Urol. 1993; 150:379.

Senthilkumar K, Arunkumar A, Sridevi N, Vijayababu MR, Kanagaraj P, Venkataraman P, Aruldhas MM, Srinivasan N, Arunakaran J. Chemoprevention of MNU and testosterone induced prostate carcinogenesis by calcitriol (vitamin $\mathrm{D}_{3}$ ) in adult male albino wistar rats. Ann Cancer Res Therap. 2006; 14:12-18

Serrano M, Lin AW, McCurrach ME, Beach D, Lowe SW. Oncogenic ras provokes premature cell senescence associated with accumulation of p53 and p16INK4a. Cell 1997; 88:593-602.

Sesterhenn IA, Becker RL, Avallone FA. Image analysis of nucleoli and nucleolar organizer regions in prostatic hyperplasia, intraepithelial neoplasia, and prostatic carcinoma. J Urogenital Pathol. 1991; 1:61-74.

Shirai T, Yamamoto A, Iwasaki S, et al. Induction of invasive carcinomas of the seminal vesicles and coagulating glands of F344 rats by administration of $\mathrm{N}$ methylnitrosourea or N-nitroso-bis (2-oxypropyl) amine and followed by testosterone propionate with or without high-fat diet. Carcinogenesis 1991;12:21692173.

Simoneau AR, Gerner EW, Phung M, McLaren CE, Meyskens Jr. FL. Alpha difluoromethylornithine and polyamine levels in the human prostate: results of a phase IIa trial. J Natl Cancer Inst. 2001; 93:57-59.

Skjorten FJ, Berner A, Harvei S, et al.: Prostatic intraepithelial neoplasia in surgical resections. Relationship to coexistent adenocarcinoma and atypical adenomatous hyperplasia of the prostate. Cancer 1997; 79:1172-1179.

Slayter MV, Anzano MA, Kadomatzu K, et al. Histogenesis of induced prostate and seminal vesicle carcinoma in Lobund-Wistar rats: a system for histological scoring and grading. Cancer Res. 1994; 54:1440-1445.

Slingerland J, Pagano M. Regulation of the cdk inhibitor p27 and its deregulation in cancer. J Cell Physiol. 2000; 183:10-17. 
Song Z, Powell WC, Kasahara N, van Bokhoven A, Miller GJ, Roy-Burman P. The effect of fibroblast growth factor 8 , isoform $\mathrm{b}$, on the biology of prostate carcinoma cells and their interaction with stromal cells. Cancer Res. 200; 60: 6730-6736.

Steiner MS, Pound CR. Phase IIA clinical trial to test the efficacy and safety of toremifene in men with high-grade prostatic intraepithelial neoplasia. Clin Prostate Cancer 2003; 2:24-31.

Syed DN, Suh Y, Afaq F, Mukhtar H. Dietary agents for chemoprevention of prostate cancer. Cancer Lett 2008; 265:167-76.

Taplin ME, Balk SP. Androgen receptor: a key molecule in the progression of prostate cancer to hormone independence. J Cell Biochem. 2004; 91:483-490.

Thomson AA. Role of androgens and fibroblast growth factors in prostatic development. Reproduction 2001; 121:187-195.

Trottier G, Bostrom PJ, Lawrentschuk N, Fleshner NE. Nutraceuticals and prostate cancer prevention: a current review. Nat Rev Urol. 2010; 7:21-30.

Trottier G, Lawrentschuk N, Fleshner NE. Prevention strategies in prostate cancer. Current Oncol. 2010; 17 (Suppl 2):S4-10.

Valve EM, Nevalainenen MT, Nurmi MJ, Laato MK, MArtikainen PM, Harkonen PL. Increased expression of FGF-8 isoforms and FGF receptors in human premalignant prostatic intraepithelial neoplasia lesions and prostate cancer. Lab Invest. 2001; 81:815-826.

Vis AN, Van der Kwast TH. Prostatic intraepithelial neoplasia and putative precursor lesions of prostate cancer: a clinical perspective. BJU Int. 2001; 88:147-157.

Weinberg DS, Weidner N. Concordance of DNA content between prostatic intraepithelial neoplasia and concomitant invasive carcinoma: evidence that prostatic intraepithelial neoplasia is a precursor of invasive prostatic carcinoma. Arch Pathol Lab Med. 1993; 117:1132-1137.

Wilke AO, Morriss-Kay GM, Jones EY, Health JK. Functions of fibroblast growth factors and their receptors. Curr Biol. 1995; 5: 5000-5007.

Wills ML, Hamper UM, Partin AW, et al.: Incidence of highgrade prostatic intraepithelial neoplasia in sextant needle biopsy specimens. Urol. 1997; 49:367-373.

Woodson K, Tangrea JA, Pollak M et al. Models of metastatic prostate cancer: a transgenic perspective. Prostate Cancer Prostatic Dis. 2003; 6:204-211.

Wu CL, Yang XJ, Tretiakova M, et al. Analysis of alpha-methylacyl-CoA racemase (P504S) expression in high-grade prostatic intraepithelial neoplasia. Hum Pathol. 2004; 35:1008-1101.

Yang RM, Naitoh J, Murphy M, Wang HJ, Phillipson J, deKernion JB, Loda M, Reiter RE. Low p27 expression predicts poor diseasefree survival in patients with prostate cancer. J Urol. 1998; 159:941-945.

Young AP, Schlisio S, Minamishima YA, Zhang Q, Li L, Grisanzio C, Signoretti S, Kaelin WG. VHL loss actuates a HIF-independent senescence programme mediated by $\mathrm{Rb}$ and p400. Nat Cell Biol. 2008; 10:361-369.

Zanardi S, Puntoni M, Maffezzini M, Bandelloni R, Mori M, Argusti A, Campodonico F, Turbino L, Branchi D, Montironi R Decensi A. Phase I-II Trial of Weekly 
Bicalutamide in Men with Elevated Prostate-Specific Antigen and Negative Prostate Biopsies. Cancer Prev Res. 2009; 2:377.

Zhou M, Shah R, Shen R, Rubin MA. Basal cell cocktail (34betaE12 _ p63) improves the detection of prostate basal cells. Am J Surg Pathol. 2003; 27: 365-371.

Zlotta A, Schulman C. Clinical evolution of prostatic intraepithelial neoplasia. Eur Urol. 1999; 35:498-503. 


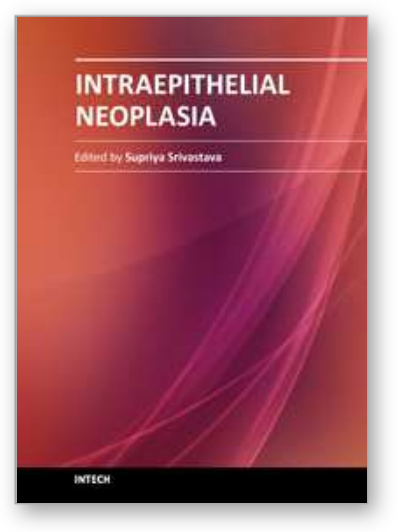

\author{
Intraepithelial Neoplasia \\ Edited by Dr. Supriya Srivastava
}

ISBN 978-953-307-987-5

Hard cover, 454 pages

Publisher InTech

Published online 08, February, 2012

Published in print edition February, 2012

The book "Intraepithelial neoplasia" is till date the most comprehensive book dedicated entirely to preinvasive lesions of the human body. Created and published with an aim of helping clinicians to not only diagnose but also understand the etiopathogenesis of the precursor lesions, the book also attempts to identify its molecular and genetic mechanisms. All of the chapters contain a considerable amount of new information, with an updated bibliographical list as well as the latest WHO classification of intraepithelial lesions that has been included wherever needed. The text has been updated according to the latest technical advances. This book can be described as concise, informative, logical and useful at all levels discussing thoroughly the invaluable role of molecular diagnostics and genetic mechanisms of the intraepithelial lesions. To make the materials easily digestive, the book is illustrated with colorful images.

\title{
How to reference
}

In order to correctly reference this scholarly work, feel free to copy and paste the following:

J. Arunakaran, S. Banudevi and A. Arunkumar (2012). Chemopreventive Target for Prostate Cancer: Prostatic Intraepithelial Neoplasia, Intraepithelial Neoplasia, Dr. Supriya Srivastava (Ed.), ISBN: 978-953-307-987-5, InTech, Available from: http://www.intechopen.com/books/intraepithelial-neoplasia/chemopreventive-target-forprostate-cancer-prostatic-intraepithelial-neoplasia

\section{INTECH}

open science | open minds

\author{
InTech Europe \\ University Campus STeP Ri \\ Slavka Krautzeka 83/A \\ 51000 Rijeka, Croatia \\ Phone: +385 (51) 770447 \\ Fax: +385 (51) 686166 \\ www.intechopen.com
}

\author{
InTech China \\ Unit 405, Office Block, Hotel Equatorial Shanghai \\ No.65, Yan An Road (West), Shanghai, 200040, China \\ 中国上海市延安西路65号上海国际贵都大饭店办公楼405单元 \\ Phone: +86-21-62489820 \\ Fax: +86-21-62489821
}


(C) 2012 The Author(s). Licensee IntechOpen. This is an open access article distributed under the terms of the Creative Commons Attribution 3.0 License, which permits unrestricted use, distribution, and reproduction in any medium, provided the original work is properly cited. 